\title{
Development of a Green City Concept Through Waste Management to Increase Community Income
}

\author{
Rukhayati $^{1}$, Sri Haryani ${ }^{2}$, Pariyati ${ }^{3}$ \\ \{rukhayatiumar@gmail.com¹, sriharyanibuna04@gmail.com ${ }^{2}$, pariyati24@gmail.com ${ }^{3}$ \} \\ Departement of Economics, Universitas Muhammadiyah Palu ${ }^{1}$, Departement of Economics, \\ Universitas Muhammadiyah Palu ${ }^{2}$, Departement of Social and Political Science, Universitas \\ Muhammadiyah Palu ${ }^{3}$
}

\begin{abstract}
The development of the green city concept has not been accompanied by the increasing volume of high waste production in Palu City. Of course, this condition is a special note for the government in making Palu a waste-free city. To help realize zero waste and realize the concept of a green city, this research aims explicitly to determine the leading waste management program that has been carried out at TDs3R Avosalae in Palu City, then to empower the community about how the market potential and marketing strategies for utilizing this waste the results of processing will be disseminated to the public. Besides, this activity is expected to be able to move from upstream to Silae village, so that this program can improve the welfare of the community and provide an example for other villages to help create a waste-free city of Palu by moving waste innovation into economic goods in an effort increase in community income.
\end{abstract}

Keywords: Waste, participation, added value, sustainable

\section{Introduction}

The issue of green city implementation has become increasingly interesting to test. This is related to the assumption that a green city itself is the government's plan to create a city with good governance, characterized by an environmentally friendly theme that can use natural resources in a balanced manner to create a prosperous society. Urban development, accompanied by an increase in population size and density and an increase in the community's socio-economic activities, will result in an increasing amount of waste from day today. Garbage is a life consequence that often causes problems, and the amount will increase along with the increase in community activities. [1]

The rapid development has an impact on the growing problem of waste in Palu City. This can be seen from the increasing population, which resulted in the high volume of waste produced in Palu City. In everyday life, humans cannot be separated from garbage; whether it is garbage that must be disposed of at home, at the office, or where we are, this makes the volume of waste increase. Of course, this condition is a special note for the city government in realizing a waste-free city. The city government has implemented a Waste Management Strategy with the $3 R$ principle (reuse, reduction, recycle) as regulated in the Palu city regional regulation to create zero waste. [2]

TDs3R (Temporary Dumpsite Reuse, Reduction, Recycle) is one indicator of environmental management's success in dealing with waste problems by following under the 
government's plan to realize the waste management program. [3], [4]. The role of all stakeholders is essential so that there is no shrinkage of green space. Therefore in the provision of green open space, it is not only the task of the government, but the community also has the right to obtain information openly about the planning and arrangement of green open space, which is responsible for managing green open space so that its sustainability, beauty, and function can be maintained appropriately, and play a role in increasing independence, growing to develop pioneering community skills, provision of privately owned land or land for organizing, green open space, and utilizing and administering green open space in yards. Especially considering that existing environmental problems require the participation and responsibility of everyone to participate in solving them. [5]

As it is known, the government's waste is not managed by the community by burning $35 \%$, burying $7.5 \%$, composted $1.6 \%$, or by other means $15.9 \%$. [6] The presence of TDS3R itself mandates that waste management is not only the government's obligation, but waste management is the responsibility of the community and business actors. TDs $3 \mathrm{R}$ is a Temporary Protection Place with the $3 \mathrm{R}$ principle (Reduce, Reuse, Recycle), from now on abbreviated as TDs3R, is a place before waste is transported to the recycling location. Then the waste is collected, sorted, reused, or recycled at an area scale. [3]

TDs3R is a Temporary Dumpsite with $3 R$ principles (reduce, reuse, recycle), from now on abbreviated as TDs3R, is a place before the waste is transported to the recycling location. Then the waste is collected, sorted, reused, or recycled on a regional scale. [6]. TDs3R is a pattern of waste management approaches at a communal or regional scale. This is done with the community's active role in the form of empowerment for low-income people who live in dense and slum areas. Waste management using TDs3R infrastructure is more directed at reducing, utilizing, and treating waste from sources, which are expected to reduce the quantity and improve the characteristics of the waste before it is further processed at the landfills. [7]

This research specifically aims to determine the development of economic activities through the waste management program that has been carried out at TDs3R Avosalae in Palu City, including whether these programs provide positive input to the surrounding community. The next objective is to analyze other TDs3R Avosalae Palu City's role in supporting waste management activities and a green city concept. It is hoped that this activity can move from the upstream to the downstream of the Silae community so that this program can improve the welfare of the community and provide an example for other urban villages to participate in realizing the waste-free city of Palu and the concept of a green city with the movement of innovating waste into economic value goods.

Waste will have economic value if insufficient quantities are to be traded or processed further as economic goods, both as raw material (recycled) and as a trading commodity. If the community as the waste producer participates in waste management, 3R (reduce, reuse, and recycle), then accommodate and market.

\section{Research Method}

\subsection{Time and Site of Research}

This research was conducted in January-March 2020. The researchers used a descriptive research approach, to be precise, using qualitative descriptive research because the researcher intended to describe how waste management in Talise Palu District, the research site is the research location or research locus. The location of this research is the area of Talise District, 
to be precise, TDs3R Avosalae Palu City. This type of research is qualitative, so the sampling technique chosen is the snowball sampling system (snowball sample), namely the technique of determining the sample, which is initially small in number. This sample has more friends to be sampled, meaning that the researcher is pointing wrong. One key informant and the critical informant appointed the next informant [8]. These considerations are associated with a small population, so that one informant is asked to show several experts who can be interviewed, then the required number of respondents is obtained. The informants in this study were: Head of Section of Environmental Control and Research Division of Central Sulawesi Province, Head of Implementing Section of Central Sulawesi Regional Settlement Facility, Official Commitment Maker for Environmental Health for Settlements in Central Sulawesi, and Head of TDs3R Avosalae Manager for Palu City.

\subsection{Data Analysis Method}

Methods of activities that will be carried out through socialization, introducing activities to the community of Silae Village, Ulujadi District, Palu City, field surveys, studying the environmental conditions of Silae Village, Ulujadi District, and social and cultural situations, business management education and training, this activity is carried out in a series of activities Entrepreneurship Motivation. This material focuses on adding insight into the strategy of pioneering and developing a waste management business and Management Development, providing knowledge of group management with good management, which aims to increase the income and welfare of its members.

The collecting data technique is done by observation, interview, and documentation. [9]. This research's analysis model is descriptive qualitative analysis, an analytical method that uses an analytical approach from the researcher's point of view as the primary analysis tool. In this analysis method, the results of exploration are presented or described to answer the formulation of research problems. Other data will also complement data analysis to get more complete results. [8]. Measurements carried out in this study are in the form of direct measurements using a Likert scale (1 to 5) to obtain a category of answers, the results of informants' responses in an interview, to be able to provide an interpretation of the frequency distribution found is large or small. [8]. The primary data source in qualitative research is words or actions; the rest is additional data, such as documents, photos, etc. In this regard, the types of data used in this study are words or actions, written data sources, photos, and statistics. [8], efforts to maintain credibility in research are through the following steps: Extension of observations, increasing persistence, triangulation, using reference materials, and using member checks. [8]

\section{Results and Discussion}

\subsection{Increase in the economic value of the product}

Most of the waste management programs appear from community/environmental activists, and although the waste management policy has been effective, it has not been optimally implemented due to several factors. As for the impact of waste management, namely, community awareness is starting to form, additional income for the community is obtained. [10]

The results of interviews with several communities indicated that there was no program sustainability. In contrast, the community was very enthusiastic about carrying out the main 
program, which could increase the economic value of waste products and increase their income. It is the same as stated by Mrs. Hawang as the head of Temporary Dumpsite Avosalae, that the additional funds provided by the government for the management of handicraft-making training programs are only limited to completing training activities without any sustainability because there is no forum or forum as a place to accommodate all aspirations regarding continuation. As well as the results of the program.

Table 1. Strengths and Weaknesses of the Waste Management Program

\begin{tabular}{cll}
\hline No & \multicolumn{1}{c}{ Strengths } & \multicolumn{1}{c}{ Weaknesses } \\
\hline 1 & Environmentally friendly & Self-discipline \\
2 & Produce recycled items & Patience and tenacity \\
3 & Additional income & Product variations \\
\hline
\end{tabular}

From the compilation analysis results, it is found that there are advantages and disadvantages in the development of economic activities through the waste management program that has been carried out at TDs3R Avosalae, Palu City.

1. Waste management activities or programs have the advantage of being environmentally friendly, of course, they can reduce the volume of waste, its just that hard work is needed for each person to be able to discipline oneself with a small example, namely disposing of garbage in its place, waste processing programs, of the results of interviews with several people around Temporary Dumpsite Avosalae, sometimes witnessed that they still lacked discipline in disposing of trash, even though public trash bins were provided. Still, the trash they brought was just thrown away in any place, even outside the public trash bins that had been provided.

2. Good waste management can produce recycled goods. That is what Temporary Dumpsite Avosalae did. The head of the management revealed that some housewives are empowered to sort waste that can still be recycled and have economic value. These housewives are employed indeed. They must have patience and tenacity in processing and recycling processes to become goods with economic value. This is the benefit they get from the training program to recycle waste into economic goods and, of course, impact the income they earn.

3. The community around Temporary Dumpsite Avosalae, especially homemakers, garbage collectors, can feel the impact of waste management, at least reduce unemployment, which usually homemakers gather and tell each other which is useless, they can now take advantage of the opportunity to increase skills and income through waste management, it has just that a container that can accommodate their recycled products is needed, because all this time the recycled products they do are only stored in a small room, causing accumulation and can damage economic value, they need to be supported for management. The central management is marketing distribution and financial management so that the management of the Avosalae Temporary Dumpsite group is well organized. 
Table 2. Product Value Added through processing.

\begin{tabular}{|c|c|c|c|c|c|c|}
\hline No & $\begin{array}{l}\text { Processed } \\
\text { Waste }\end{array}$ & Process & Product & $\begin{array}{c}\text { Management } \\
\text { Cost Of } \\
\text { Goods Sold } \\
\end{array}$ & Selling Price & Variant \\
\hline 1 & Straw & Reuse & $\begin{array}{ll}- & \text { Wallet } \\
- & \text { Bag }\end{array}$ & $\begin{array}{l}\text { Rp. } 1.000 / \mathrm{Kg} \\
\text { Rp. } 3.000 / \mathrm{Kg}\end{array}$ & $\begin{array}{l}\text { Rp.15.000 } \\
\text { Rp. 50.000 }\end{array}$ & $\begin{array}{l}\text { Rp. } 14.000 \\
\text { Rp. } 47.000\end{array}$ \\
\hline 2 & $\begin{array}{l}\text { Plastic (Non- } \\
\text { Biodegradable) }\end{array}$ & Reuse & $\begin{array}{ll}\text { - } & \text { Wallet } \\
\text { - } & \text { Hand Bag }\end{array}$ & Rp. $600 / \mathrm{Kg}$ & $\begin{array}{l}\text { Rp. } 15.000 \\
\text { Rp. } 30.000\end{array}$ & $\begin{array}{l}\text { Rp. } 14.400 \\
\text { Rp. } 29.400\end{array}$ \\
\hline 3 & Plastic spoon & Reuse & $\begin{array}{l}\text { - Decorative } \\
\text { Flowers } \\
\text { - Lamp }\end{array}$ & $\begin{array}{l}\text { Rp. } 1.000 / \mathrm{Kg} \\
\text { Rp. } 2.000 / \mathrm{Kg}\end{array}$ & $\begin{array}{l}\text { Rp. } 25.000 \\
\text { Rp. } 60.000\end{array}$ & $\begin{array}{l}\text { Rp. } 24.000 \\
\text { Rp. } 58.000\end{array}$ \\
\hline 4 & Used Cloth & Reuse & Doormat & Rp. 0 & Rp. 50.000 & Rp. 50.000 \\
\hline 5 & Wet garbage & Recycling & $\begin{array}{l}\text { Fertilizer } \\
\text { (Sack) }\end{array}$ & Rp. 0 & Rp. 15.000 & Rp. 15.000 \\
\hline 6 & $\begin{array}{l}\text { Plastic } \\
\text { (Mineral } \\
\text { Bottle) }\end{array}$ & Reuse & $\begin{array}{l}\text { Decorative } \\
\text { Flowers (Large } \\
\text { Size) }\end{array}$ & Rp. 6.000 & Rp. 100.000 & Rp. 94.000 \\
\hline
\end{tabular}

The increase in the product's economic value can be seen in Table 2, where it turns out that an item that is considered worthless turns out to have a reasonable value after being processed, so it needs more organized management. The results of the processing that has been done can provide additional income. Creating jobs will also reduce the unemployment rate and automatically increase income for low-income people in the Silae Village, Palu City, to participate in managing waste into compost and crafting plastic waste into handicrafts. Community empowerment through waste management is expected to improve the welfare of the community in Silae Village. Besides, it is hoped that it can become a pilot for other urban villages or even for the private sector to make waste innovations into economic value goods, which will ultimately make Palu a green and waste-free city.

\subsection{The participation of TDs3R Avosalae in supporting waste management activities and developing the green city concept}

The hope of changing people's views in assessing waste as an alternative resource can be done by reusing it through a recycling process or using it directly, where waste is converted into a reduced at source and resource recycle approach through the implementation of the reuse, reduction, recycle. There are five stages of waste handling: sorting, collecting, transporting, processing, and finalizing waste. With this waste processing, it is hoped that it can minimize the piles of waste disposed of in the landfills. [7]

Green city development itself includes "three pillars of sustainability theory and a variety of other issues such as health, greenery, resilience, and equity. Environment-related issues are by far the most often presented in green city definitions, concepts and methods "[11]; in simple terms, it can be assumed" Cities are responsible for many of our current global environmental challenges, ranging from air pollution to sanitation issues. [12]

In applying the concept of green cities and waste management, public awareness is urgently needed by the community to apply reuse, reduction, recycle management methods: carrying shopping bags, buying recycled products, repairing and reusing old products, separating organic and inorganic waste, and making handicrafts from used materials. [13] Besides that, their understanding of green cities needs to be improved through sustainable 
socialization. Government support is also urgently needed by providing space for people to participate in waste management actively. People can take advantage of waste processing as an alternative to economic activities to produce recycled products from waste. Of course, economic value can lead to innovations in the use of waste, including recycled products that have been exhibited at both local and national events, organic and inorganic fertilizers. This is what makes Avosalae Temporary Dumpsite a pilot area for waste management.

Table 3. Frequency and Percentage of waste management activities and development of green city concept

\begin{tabular}{|c|c|c|c|c|c|c|c|c|c|c|c|c|c|}
\hline \multirow{3}{*}{$\begin{array}{c}\mathrm{Nu} \\
\mathrm{mbe} \\
\mathrm{r}\end{array}$} & \multirow{3}{*}{ Description } & \multirow{2}{*}{\multicolumn{2}{|c|}{$\begin{array}{c}\text { Total } \\
\text { Disagree } \\
\text { (Bobot 1) }\end{array}$}} & \multirow{2}{*}{\multicolumn{2}{|c|}{$\begin{array}{l}\text { Disagree } \\
\text { (Bobot 2) }\end{array}$}} & \multirow{2}{*}{\multicolumn{2}{|c|}{$\begin{array}{l}\text { Answer } \\
\text { Doubtful } \\
\text { (Bobot 3) }\end{array}$}} & \multirow{2}{*}{\multicolumn{2}{|c|}{$\begin{array}{c}\text { Agree } \\
\text { (Bobot 4) }\end{array}$}} & \multirow{2}{*}{\multicolumn{2}{|c|}{$\begin{array}{l}\text { Strongly } \\
\text { Agree } \\
\text { (Bobot 5) }\end{array}$}} & \multicolumn{2}{|c|}{ Amount } \\
\hline & & & & & & & & & & & & \multirow[t]{2}{*}{$\mathrm{F}$} & \multirow[t]{2}{*}{ Score } \\
\hline & & $\mathrm{F}$ & $\%$ & $\mathrm{~F}$ & $\%$ & $\mathrm{~F}$ & $\%$ & $\mathrm{~F}$ & $\%$ & $\mathrm{~F}$ & $\%$ & & \\
\hline 1 & $\begin{array}{l}\text { Environmenta } \\
1 \text { awareness }\end{array}$ & 2 & 4,5 & 10 & 22,7 & 25 & 56,8 & 1 & 2,3 & 6 & 13,6 & 44 & 131 \\
\hline 2 & $\begin{array}{l}\text { Education and } \\
\text { Experience }\end{array}$ & 1 & 2,3 & 5 & 11,4 & 26 & 59,1 & 1 & 2,3 & 11 & 25,0 & 44 & 148 \\
\hline 3 & $\begin{array}{l}\text { Understandin } \\
\mathrm{g} \text { the concept } \\
\text { of green cities }\end{array}$ & 1 & 2,3 & 8 & 18,2 & 0 & 0 & 30 & 68,2 & 5 & 11,4 & 44 & 162 \\
\hline 4 & $\begin{array}{l}\text { Waste } \\
\text { treatment as } \\
\text { an alternative } \\
\text { to economic } \\
\text { activities }\end{array}$ & 1 & 2,3 & 0 & 0 & 32 & 72,2 & 1 & 2,3 & 10 & 22,7 & 44 & 151 \\
\hline 5 & $\begin{array}{l}\text { Supporting } \\
\text { facilities for } \\
\text { processing }\end{array}$ & 1 & 2,3 & 5 & 11,4 & 26 & 59,1 & 1 & 2,3 & 11 & 25,0 & 44 & 148 \\
\hline & $\begin{array}{l}\text { Total Value } \\
\text { Maximum Value }\end{array}$ & & 2,74 & & 12,7 & & 49,5 & & 15,4 & & 19,5 & & $\begin{array}{r}740 \\
1100\end{array}$ \\
\hline & Total Application & f & sete & 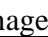 & te & & & & & & U & & 0,67 \\
\hline
\end{tabular}

The application of waste management activities and the development of the green city concept in table 3 shows that the environmental awareness level of the community to create a clean and healthy environment still needs to be regenerated, so it needs regular socialization, from the results of interviews that some people still have not separated their types of waste and because There are Temporary Dumpsite that are far apart so that the garbage is dumped just anywhere. The local housewives makes a regular community service program; it's just that not all community members participate because of their respective busyness even though their enthusiasm is very high for the sake of a clean and healthy environment. The environment will be clean and healthy because all waste can be utilized. The community will benefit indirectly.

Some people experience a lack of understanding of the concept of green cities related to waste management. However, the results of their interviews suggest that tree planting, environmental cleanliness, an arrangement of city parks, and the provision of landfills by type are partly understood by the community only in its implementation. Must be improved, education is needed related to complex environmental problems due to an increase in the volume of waste; this is necessary to build public awareness. The formation of community organizations is generally based on environmental-based community empowerment. Handling 
household waste is not an easy problem. The amount of waste production is large every day, and of course, the various types of materials cannot be processed simultaneously. [14] The leading proponent of environmental concerns is based on thinking and, of course, how society behaves itself. Active community participation is an essential thing in waste management actions and other supporting facilities and infrastructure.

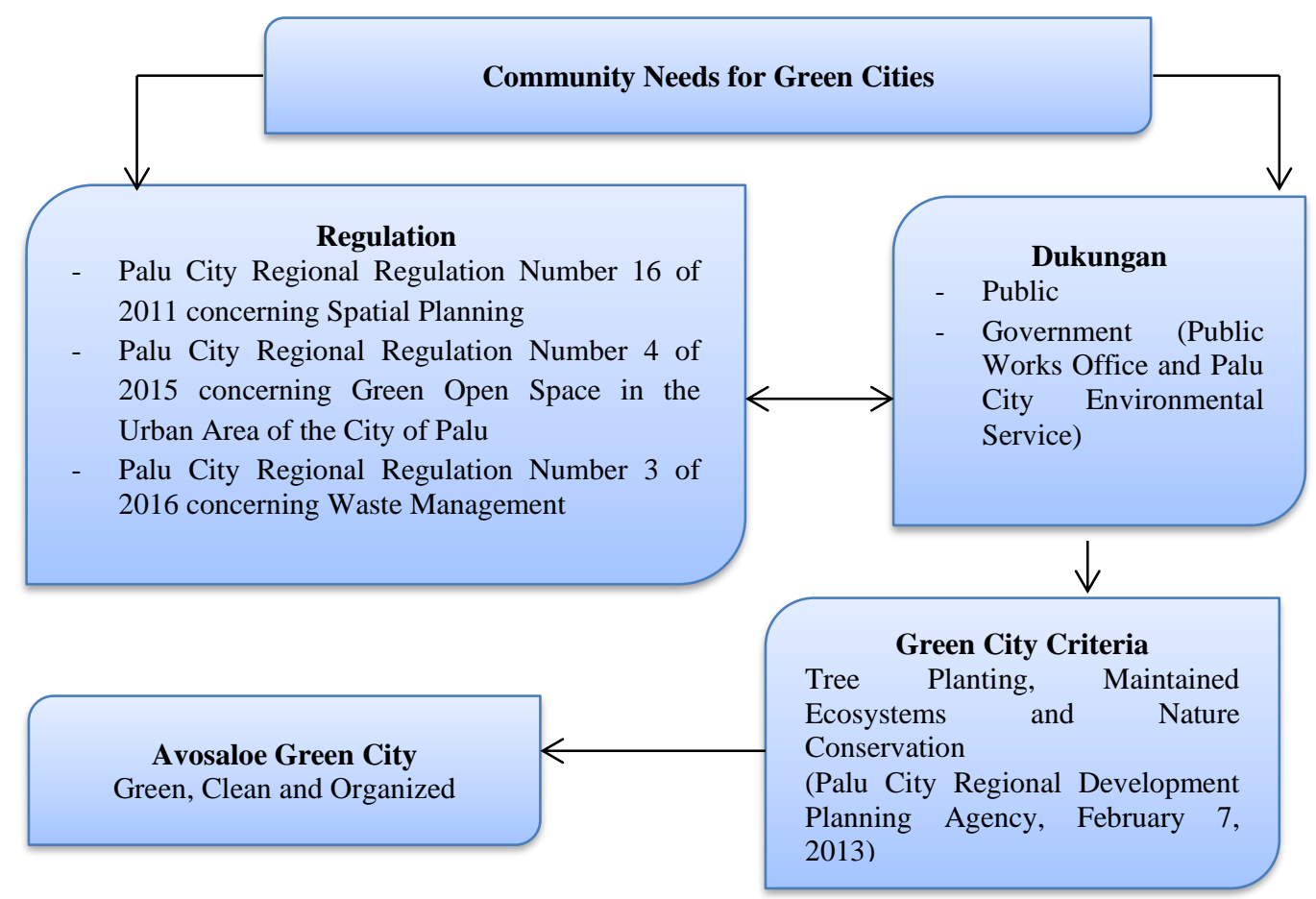

Figure 1. Implementation Model of the Green City "Avosalae” Concept

Figure 1 above, in principle, shows a model of the green city concept of Avosalae. In principle, Temporary Dumpsite Avosalae is a waste processing place with the $3 \mathrm{R}$ concept (reduce, reuse, and recycle) as a form of reducing waste volume. In its implementation and management, it involves the active role of the government and the community so that the success of the waste processing program and the concept of green cities become successful thanks to the community's active role, of course, from socialization to utilization and maintenance, waste management requires serious attention; the handling process as a learning medium becomes a useful parameter with an environmental perspective to foster a caring character for the environment for all of us. [15]

\section{Conclusion}

The implementation of the waste processing program is still not optimal; this is due to the low participation of the community, even though only partially, but in its implementation, the level of awareness and concern remains the main factor in the success of the program to create an environmentally friendly green city and create economic activities in the form of a processing program. Waste into products of economic value. To ensure the sustainability of 
the program, it is necessary to establish integration between the government regarding finance and the provision of facilities and infrastructure and human resource training.

The need for a forum or forum as a place to convey ideas or opinions, so that what becomes the complaints and hopes of the community can be channeled, besides that the role of the government and other private institutions can become the media in the distribution of the marketing of recycled products that have been carried out, government participation, related institutions who will accompany program activities. The form of assistance is to provide strengthening in entrepreneurship and marketing of local products. This collaboration in marketing shows the government institutions' attention to the community to do business and is a form of the concept of business sustainability.

\section{References}

[1] D F Nudiana, T Yuningsih and Maesaroh 2015 Studi Kualitatif Pengelolaan Sampah di Kecamatan Banyumanik Kota Semarang J Public Policy Manag 4, 3 p.1-9

[2] Peraturan Daerah Kota Palu Nomor 3 Tahun 2016 Pengelolaan Sampah Wali Kota Palu Provinsi Sulawesi Tengah

[3] Menteri Pekerjaan Umum Peraturan Mentri Pekerjaan Umum Republik Indonesia Nomor/3/PRT/M/201 2013 Tentang Penyelenggaraan Prasarana dan Sarana persampahan dalam Penanganan Sampah Rumah Tangga Dan Sampah Sejenis Sampah Rumah Tangga p.1374

[4] Peraturan Pemerintah Republik Indonesia Nomor 812012 Pengelolaan Sampah Rumah Tangga dan Sampah Sejenis Rumah Tangga Presiden Republik Indonesia

[5] D Rahmadhani, H Purnaweni, and Aufarul Marom 2019 Implementasi Kebijakan Ruang Terbuka Hijau Privat Di Kecamatan Pedurungan Kota Semarang J Chem. Inf. Model 53, 9 p.1689-1699

[6] Y Trihadiningrum Perkembangan Paradigma Pengelolaan Sampah Kota Dalam Rangka Pencapaian Millenium Development Goals

[7] Kementrian Pekerjaan Umum \& Perumahan Rakyat Direktorat Jendral Cipta Karya 2016 Direktorat Pengembangan penyehatan Lingkungan Permukiman (2017) Petunjuk Teknis TPS3R Tempat Pengolahan Sampah 3R 53, 9 p.1689-1699

[8] Sugiyono 2013 Metode Penelitian Kuantitatif Kualitatif Dan R\&D Bandung Alfabeta

[9] Undang-Undang Nomor 18 Tahun 2008 Pengelolaan Sampah

[10] Lestari A P, Soeaidy M S \& Said A 2013 Program Pengelolaan Inovasi Sampah di Kota Malang Jurnal Administrasi Publik (JAP) 2, 3 p.571-577

[11] O Brilhante and J Klaas 2018 Green city concept and a method to measure green city performance over time applied to fifty cities globally Influence of GDP population size and energy efficiency Sustain 10, 6 DOI 10 3390/su10062031

[12] S M Müller and A Mattissek 2018 Green City transformations in environment and Society explorations and Visions of Urban Sustainability [Online] Available www.environmentandsociety.org/perspectives

[13] M Zamroni, R S Prahara, A Kartiko D Purnawati and D W Kusuma 2020 The Waste Management Program of 3R (Reduce, Reuse, Recycle) by Economic Incentive and Facility Support J Phys. Conf. Ser. 1471, 1 p.1-6 DOI 10 1088/1742-6596/1471/1/012048

[14] M E Ferdiansyah and A Arsiyah 2014 Peran Pemerintah Dan Kader Masyarakat Dalam Pemberdayaan Masyarakat Untuk Pengolahan Sampah JKMP (Jurnal Kebijakan dan Manajemen Publik) 2, 2 p.191 DOI 10 21070/jkmp v2i2 438

[15] R D Arisona 2018 Pengelolaan Sampah 3R (Reduce Reuse Recycle) Pada Pembelajaran IPS Untuk Menumbuhkan Karakter Peduli Lingkungan Al Ulya J Pendidik Islam 3, 1 Edisi Januari-Juni 